RAPHISA.

Revista de Antropología y Filosofía de lo Sagrado

Review of Anthropology and Philosophy of the Sacrum

ISSN: 2530-1233 N 1, enero-junio (2017) pp.: 81-100

\title{
HEGEL AND THE IMAGE THEORIES OF THE LATE ANTIQUITY ${ }^{1}$
}

\section{HEGEL Y LAS TEORÍAS DE LA IMAGEN DE LA TARDOANTIGÜEDAD}

\author{
Haris Ch. Papoulias ${ }^{2}$ \\ University of Eastern Piedmont (Italy)
}

\begin{abstract}
The aim of this essay is to explore a field of studies that until now has not gained the attention of the Hegelian scholars: the relationship between the Hegelian Philosophy and the philosophies of the Late Antiquity. The paper is divided in two parts, following what I consider the change of paradigm in image theories, during the passage from the Pagan to the Christian world. In the first part I consider Hegel's thesis on what we could call the Greek image theory, defined by the rationality of the human figure, until its slow decay. Such a decay will not be a simple disappearance but a transformation to what would later be the new principle for a Christian image theory: the speculative likeness. At the end of this essay, I will try to highlight the principle that undergoes the whole Hegelian treatment and that corresponds not to historical or empirical facts, but to his gnoseological theory, developed in the section of the Subjective Spirit in his Encyclopedia of the Philosophical Sciences. The whole essay should be considered as a brief contribution to the construction of what is aimed to be a Hegelian theory of images and particularly to what I call "endogenous iconoclasm of the image".
\end{abstract}

Key words: Hegel - Late Antiquity - Image Theory - Endogenous Iconoclasm - Subjective Spirit.

Resumen: El objetivo de este ensayo es explorar un campo de estudio que hasta ahora no ha llamado la atención de los especialistas: la relación entre la filosofía hegeliana y las filosofías de la Tardoantigüedad. El siguiente trabajo está dividido en dos partes, siguiendo lo que considero el cambio de paradigma en las teorías de la imagen durante el

[1] This work is a development of an outline presented in the 14th Conference of the International Society for the Study of European Ideas (ISSEI, Porto, Portugal 2014), entitled Images of Europe: Past, Present, Future.

[2] (haris.papoulias@uniupo.it) - Haris Ch. Papoulias es investigador doctoral en la Universidad del Piamonte Oriental (Italia), es miembro-fundador del Centro de Estudios sobre Hegel en la misma universidad (www.hegelab.com) y aspirante a Doctor Europaeus (Universidad de Málaga, España). Realiza su tesis doctoral sobre la fundación de una teoría de la imagen en el sistema hegeliano. Sus líneas de investigación se centran en la iconoclasia y las relaciones entre imagen, filosofía, arte y religión. 
pasaje del paganismo al mundo cristiano. En la primera parte se examina la tesis de Hegel que podríamos llamar la teoría griega de la imagen, definida por la racionalidad de la figura humana, hasta su lento declive. Tal declive no será una simple desaparición, sino una transformación de lo que más tarde será un nuevo principio para una teoría cristiana de la imagen: la semejanza especulativa. Al final de este ensayo, trataré de evidenciar el principio que subyace en toda la doctrina hegeliana y que no corresponde a hechos históricos o empíricos, sino a su teoría del conocimiento, desarrollada en la sección del Espíritu Subjetivo en su Enciclopedia de las Ciencias Filosóficas. El ensayo en su totalidad debería ser considerado una breve contribución a la construcción de lo que estará destinado a convertirse en una teoría de la imagen hegeliana y espe- cíficamente en el desarrollo de lo que considero una "iconoclasia endógena de la imagen".

Palabras Clave: Hegel - Tardoantigüedad - teoría de la Imagen - iconoclasia endógena - Espíritu Subjetivo.

\section{Introduction}

To initiate a research about image theories in the late antiquity and about how Hegel has considered them in his philosophical doctrine means, in a certain way, to take on a triple challenge. After a long tradition of Hegelian studies, it is not difficult for us today to bump into many essays, for instance, on "Hegel and Modernity"; the same we could say about "Hegel and the Greeks", that naturally drew the attention of great philosophers as Heidegger and Gadamer; but we could find almost none on "Hegel and the Medieval Thought", or - as far as I know - on "Hegel and the Late Antiquity". A reason could be that the historical period of late antiquity is problematic even just in its definition. The very term "late antiquity" has been used for the first time only in the first decade of the 20th century and, until now, many scholars are still in disagreement on the exact centuries comprehended by that term ${ }^{4}$. Nevertheless, as our aim

[3] There are, of course, studies on Hegel and single philosophers of the late antiquity, as Plotinus or Proclus, but even so, I think it still remains an obscure topic and as far as I know, it has never done a study on how Hegel sees philosophically this historical period. For one recent study on Hegel and a Medieval philosopher, see: CAtarina Belo, Averroes and Hegel on Philosophy and Religion, Ashgate, 2013; on Hegel and the late antiquity, see the important contribution of W. Beierwaltes, "Hegel und Plotin", in Revue Internationale de Philosophie, 24 (1970), pp.348-357. See also the bibliography of the volume: "Hegel and the History of Philosophy", Proceedings of the 1972 Hegel Society of America Conference, ed. by J. J. O'MaLLEY, K.W. Awozin, and F.G. Weiss, The Hague: 1974, pp. 204 ff.; it seems indicative that in this volume, there are two essays on Hegel and Platonism but none on the late antiquity.

[4] In fact, Hegel does not speak namely about the "late antiquity", since the German term Spätantike has been coined much later, at the beginnings of 20th century. Perhaps one of 
is not a historical but a philosophical consideration, we could simply declare the span of centuries that we would like to examine and go further. Unfortunately there are still more problems for a Hegelian approach to our topic. The topic of images, for instance, is another problematic issue in Hegelian studies. In the best case, there is almost a complete absence of papers on Hegel and images; in the worst case, sporadic references to this issue of images describe Hegel as an iconoclast that disregards all the problems of the figural representation. His System, too, is said so many times to be a hostile System to every form of knowledge except for the conceptual one.

A third element that we have to consider here, in order to make a sufficient exposition of our argument, is the importance of images in the late antiquity - independently of what Hegel knew or wrote about it. Again we could find ourselves in a rarely explored field ${ }^{5}$. It is only after the general spread of contemporary image-theories that the era of "late antiquity" has been investigated with regard to this topic. For that reason, I believe it would be useful to refer to that period throughout texts on images by authors as Philo of Alexandria, Plotinus, or the Greek Church Fathers, even if Hegel himself - except generic quotations - rarely literally quotes $^{6}$. I tried to expose, thus, Hegel's observations on the philosophical

the first to use it is Alois Riegl, in his work Die spätrömische Kunstindustrie (Wien: 1901); even if he prefers to use the word "spätrömische", he explains that what he really means is not the art or history of Rome or Italy, but of Greeks during the reign of Constantine, up to the time of Charles the Great (see his introduction to the Spätrömische Kunstindustrie); that is to say, he means what other scholars would simply call "Byzantine". In the same period, another great art historian, Ernst Kitzinger, calls it, in fact, "Byzantine" (see his Byzantine Art in the Making: main lines of stylistic development in Mediterranean art, 3rd-7th century, Cambridge: 1977).

[5] The only study expressively dedicated to the visual question in the era of the late antiquity, as far as I know, is the pioneer work of ViтTORIo FAzzo, La giustificazione delle immagini religiose dalla tarda antichità al cristianesimo, Edizioni Scientifiche Italiane, Napoli: 1977; it is frequent the appearance of specialized papers of conference proceedings as Incontri triestini di filologia classica (4), 2004-2005: Atti del Convegno Internazionale Phantasia. Il pensiero per immagini degli antichi e dei moderni ed. by L. CRISTANTE, TRIESTE: 2006; or studies dedicated to the visual issue in a broader sense, as the book of G. Frank, The memory of the eyes: pilgrims to living saints in Christian late antiquity, University of California Press, Berkeley and Los Angeles: 2000; see also James A. Francis, "Visual and Verbal Representation: Image, Text, Person, and Power", in: A companion to late Antiquity, ed. by Ph. Rousseau, Blackwell, 2009, pp.285-305.

[6] For instance, he never mentions by name any single author of the Patristic tradition, but their importance is undoubted because of the large space that he devotes to them during his lectures. Furthermore, we are sure of his good knowledge of them, also because of his early studies in Theology in Tubingen's Stift; for a special treatment of Hegel's studies there, see: A. TAssi, G.W.F. Hegel e gli anni di Stuttgart e Tübingen: 1785-1793, Guerini e Associati, Milan: 1996. 
value of images, in connection to the main sources of that period; in that way, I think, we could appreciate Hegel's words and details, otherwise read as coincidental commentaries beyond the main theoretical exposition. On the contrary, as we will see, his opinion has been clearly produced by a profound reflection on the literature, from the Hellenistic to the Patristic era. If this is generally known as one of the most problematic periods of the Western history, also because of the split and convergence of philosophy and religion, it will be even more interesting to discover how the "Philosopher of Reconciliation" par excellence, has actually elaborated all these conflicts.

Given these discouraging premises we can understand well the importance of putting all the elements together in order to obtain a new vision on both Hegelian philosophy and image theory. I divided this paper in two parts, following what I consider the change of paradigm in image theories, during the passage from the Pagan to the Christian world. In the first part I consider Hegel's thesis on what we could call the Greek image theory, defined by what we present as the principle of their image-theory: the rationality of the human figure, until the slow decay of the very same principle. Such a decay was not a simple disappearance but a transformation to what would later be the new principle for a Christian image theory, that is to say, what I call here the speculative likeness. At the end of this essay, I will try to highlight the principle that undergoes the whole Hegelian treatment and that corresponds not to historical or empirical facts, but to his gnoseological theory, developed in the section of the Subjective Spirit in his Encyclopedia of the Philosophical Sciences.

Just before starting my examination, I have to admit that a brief essay will not be enough to establish a permanent and well-founded connection between all these elements. For instance, as we will see at the end of the paper, the relation between Hegel and the Gnostic doctrine is much more complicated than what could be analyzed here. Thus, I will pointout only the principles that lay behind a complex image theory that still wait for a systematic treatment. However, I am convinced that gathering together this kind of material could be the first step for a broader future investigation, under a new point of view that will be fruitful for both Hegel scholars and image-theorists.

\section{The Rationality of Human Figure}

The great importance of an aesthetic approach to history, for Hegel, is clear by the way in which he treats the Greek World. He doesn't divide the Greek eras in a simple historical way (as "Archaic", "Classical" 
or "Hellenistic" would indicate) but-clearly influenced by an aesthetical pproach-he identifies three of them, calling them namely "subjective, objective and political work of art".

First, however, we have to say that it is surprising to find the real ground of an image theory, the main principle able to distinguish between iconic and an aniconic theory, also in his Lectures on Philosophy of History. That is given by Hegel in these terms:

But if it were asked: Does God necessarily manifest himself? (muß Gott erscheinen?) the question must be answered in the affirmative; for there is no essential existence that does not manifest itself?

This passage is of great importance to us, because it is a confirmation by Hegel of what in his Science of Logic is the very beginning of the chapter on "Appearance" in the Doctrine of Essence. This chapter is the first and absolute standpoint for any philosophical justification of images. Nonetheless, "Appearance" does not mean already artistic appearance, or artistic image.

The need to portray God through fine art arises only when the sphere of natural life is left behind. [...] The way in which he manifests himself and becomes apparent in his determinate being is determined from within, by the spirit, and exhibits in itself the character of a spiritual production. It is not a mere natural appearance, not a mere sign' .

I would like to note some points: First, what the word "sign" means here is not what "sign" means in a general theory of knowledge. The logic of its function is the same, but here what the sign means is something taken from the natural world. A sign, in a knowledge theory, is, on the contrary, something posited by the intelligence in order to liberate us from sensibility. But, secondly, we have to assume that Hegel makes a very thin distinction between a mere image and an artistic image. Greeks have not invented the figural image; in a certain way they invented something

[7] W.: G.W.F. HeGEL, Werke in zwanzig Bänden, ed. by E. Moldenhauer and K. M. Michel, Suhrkamp, Frankfurt a.M. 1970, Bd.12: Vorlesungen über die Philosophie der Geschichte, p. 305; Engl. transl.: LPhH: The Philosophy of History, trans. by J. Sibree, Kitchener, London: 1858, reprint, Ontario: 2001, p. 267; see also: V.: G.W.F. Hegel, Vorlesungen. Ausgewählte Nachschriften und Manuskripte, Bd.12: Vorlesungen über die Philosophie der Weltgeschichte, Berlin 1822/23, ed. by K.H. Ilting, K. Brehmer and H.N. Seelmann, Hamburg 1996, p. 372.

[8] V4a: Vorlesungen über die Religionsphilosophie, Bd.4a: Die bestimmte Religion, ed. by W. Jaeschke, Hamburg 19942, p. 275; Engl. transl.: LPhR: Lectures on the Philosophy of Religion, vol. II: Determinate Religion, trans. by P. Hodgson, University of California Press, Berkeley - Los Angeles - London: 1995, p. 374-75. 
more, since an image is not necessary a real icon, i.e. an image with a proper objectivity in itself, but is something like a fetish. Hegel reminds us that fetish comes from a Portuguese word (feitiço) which means magic; it is an object that represents not something other, but "the arbitrary choice of its maker"9.

So, the real progress for Hegel has been made by Greeks, not because they invented the figural representation, but because in such a figural representation they saw the real objective existence of the Otherness, embodied in their proper figures. This means the exact opposite of "fetish". A fetish is something that is mine, projected in the external. The Greek image is something external, made in my likeness.

What is remarkable is that Hegel deduces all these elements only by reasoning, since real progress in archeological and philological research on these subjects was made only in the 20th century. For instance, Jean-Pierre Vernant spoke about an internal progress in Greek images, from what was eidolon as a "double", to the eikon as an "image". This passage is connected to the Greek funeral traditions as a passage from an aniconic funeral monument, to a figural one, from a "mere stone" to a "kouros"10; or, in Hegel's words, from a "mere sign", to a "Greek statue"11.

What characterizes the Greeks in their production of divine images is what Hegel calls the "beautiful individuality"12 which is better expressed in human figure. "If God himself is to be manifested in a corresponding expression, that can only be the human form"13, declares Hegel. What we mean here is not about simple "personification", as what a primitive mind normally does with natural powers. Hegel, against the common belief that

[9] W12, p. 123; LPhH, p. 112: "Such a fetish has no independence as an object of religious worship; still less has it aesthetic independence as a work of art; it is merely a creation that expresses the arbitrary choice of its maker, and which always remains in his hands".

[10] See: J.-P. Vernant, Figures, idoles, masques, Julliard, Paris: 1990.

[11] In another place, Hegel says that Art spiritualizes the mere outward and material object of adoration with a form which expresses soul, sentiment, Spirit" and that it is very different for us to have a mere thing in front of us, or to contemplate a painting (W12, p. 488-89 f.; $\mathrm{LPhH}$, p. 427-28). All of these theses of Hegel are to support the necessity of Art, as the necessity of Appearance as Image.

[12] But, Hegel adds that these forms are not only human artifacts, but rather eternal truths, powers of the Spirit, created and uncreated at the same time by man's hand. Note that "the uncreated image" is a stepping stone of Christian image theory. However, Hegel uses it here in the sense of "images not created arbitrary" but by the power of the Spirit of Time.

[13] W12, p. 305; LPhH, p. 267; since "the spiritual surely cannot come forth, in the shape of a lion” (V4a, p.553; LPhR. II, p. 661). 
Greeks adored natural powers in human figures and by anticipating a provocative theory of Walter Otto, states:

\begin{abstract}
Helios is not the god of the sun - the Greeks never express themselves this way;

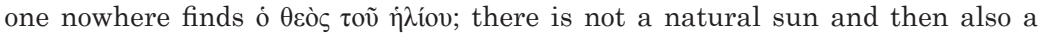
Helios as god of the sun, but rather Helios, the sun, is the god. [...] The second point, therefore, is that these powers of nature are subordinated to the spiritual ones $[\ldots]^{14}$.
\end{abstract}

In that way, the concept has a certain priority. As W. Otto claims ${ }^{15}$, it is not that the Greeks made a Goddess out of Justice, rather they called Justice the property of the namesake Goddess. In the late antiquity, one of the most important defenders of Paganism, Porphyry (A.D. 233-305), writes in defense of the statues: "[the old masters] molded their gods in human form because the deity is rational" ${ }^{16}$. But Porphyry, one of the greatest enemies of Christian intellectuals, was much closer to them than to the old Greek philosophers. Hegel has a very particular view on the subject, as he notes that Pagans are to blame not because they were anthropomorphist, but because they were not anthropomorphist enough as they had to be and definitely not as much anthropomorphist as the Christians became later! Porphyry is close to the later Byzantine Aesthetics also for another very interesting reason: he explains not only that the human figure brings rationality to the image of God and that allegory or metaphor are permitted as mediums of religious art, but that the specific choice of materials by the artists, correspond to specific determinations of the divine. To use gold, for instance, means the will to show the incorruption of the divine ${ }^{17}$.

Hegel does not enter into details, but we understand well that through certain provocative theses, as the one on the insufficient anthropomorphism, he tries to bring closer the Pagan and the Christian worlds, and by doing so, religion and philosophy too. In fact, of his contemporaries, the one who was favorable to the separation of these two worlds was Schiller, criticized by Hegel for his ingenuous modern paganism. Particularly for the verse quoted from The Gods of Greece ${ }^{18}$, where Schiller writes:

[14] V4a, p. 537; LPR, II, p. 645.

[15] See: Theophania. Der Geist der altgriechischen Religion, Frankfurt a.M.: 1993.

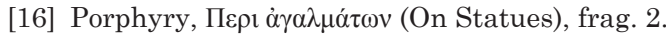

[17] Ibidem.

[18] The verse quoted from its 1 st version of 1788 here is quite different from its last version. Schiller received many objections, particularly by Graf zu Stolberg, who opened a debate between poets and critics with the aim to clarify the relations between Art and Religion, and cut them off, leaving as a conclusion the verses which Hegel most liked: "what shall live undyingly in song must pass away in life." That verse, for Hegel, confirms that "the Greek 
"Since the gods were then more human, men were more godlike". But in his Aesthetics, in a short paragraph dedicated to the passage from Antiquity to the Christian world, Hegel claims clearly that "this famous saying (...) is altogether false" as false and unilateral is Goethe's opposition to Christianity ${ }^{19}$.

Hegel does not want to think about wars between cultures. With an optimistic attitude, he prefers a solution found by internal reasons that makes historical stages follow one another. The passage from Greek to Roman art is, first of all, a decay of the Hellenic civilization from within itself. It is an internal factor. There is a chapter of his Aesthetics entitled "the dissolution of classical art in its own sphere". The loss of balance between form and content, i.e. between real and ideal, leads to the appearance of comedy as the dominant form of art by which Greek art declines. The Roman satire will only confirm this decay "externally". In any case, we must note that no other mention of Roman art is made by Hegel. Romans' function was to create a horrible void between the individual and a huge abstract State of Law. This feeling of solitude would prepare the upsurge of the Christian yearning for infinity. This yearning would demand not only the necessity of Appearance, as we saw before, but at the same time, the necessity of the disappearance of the image. I think that Hegel was worried about this issue starting at his youth. A striking passage quoted below from his unpublished drafts, now known as "The Spirit of Christianity and its Fate", attest to this:

In an Apollo or a Venus we must forget the marble, the breakable stone, and see in its shape the immortal only. In looking at the shape, we are permeated with the sense of love and eternal youth. But grind the Apollo or the Venus to dust and say "This is Apollo, this Venus," and then the dust confronts you and the images of the immortals are in you, but the dust and the divine never merge [coalesce] into one. The merit of the dust lay in its form, and the form has gone, while the dust is now the chief thing. (...) When the Apollo is ground to dust, devotion remains, but it cannot turn and worship the dust. The dust can remind us of the devotion, but it cannot draw devotion to itself. A regret arises, and this is the

gods had their seat only in ideas and imagination; they could neither maintain their place in the reality of life nor give final satisfaction to the finite spirit"; see: W14: Vorlesungen über die Ästhetik II, p. 115; Engl. transl.: Aesth.: Aesthetics. Lectures on Fine Art, trans. By T.M. Knox, Calderon Press, Oxford 1975, vol. I, p. 508.

[19] Ibidem; for Hegel, this kind of neo-paganism is the fruit of the opposition between "Greek Imagination and modern Enlightenment's abstractions of the Understanding"; in that context, Hegel also condemns Goethe, to whom every odd attitude was permitted, because his vision of Christianity was also unilateral and false (W14, p. 116; Aesth., I., p. 509). 
sensing of this separation, this contradiction, like the sadness accompanying the idea of living forces and the incompatibility between them and the corpse ${ }^{20}$.

That is to say, the beautiful individuality of the Greeks is a great vehicle to God, but only as long as the form lasts. The problem of a Greek statue is its former vantage: it gave form to what was formless, but that means that it is made as an object for the senses, and the senses do not last. We can keep the images of God inside, but such images would be only eidola, like we find in Xenophon, when in his Symposium he speaks about the images that lovers keep, one another, in their mind ${ }^{21}$. In fact, the "sense of separation" that Hegel speaks of, for the Greeks, was connected to this kind of images, under the name of pothos, that is, the desire of something absent. It is again remarkable that Hegel noted this relation between loss of form, internalization of images and sense of separation.

At that time, however, Christian solutions were appearing even worse to Hegel. "Fancy cannot bring together [God and senses] in a beautiful image", he claims, anticipating his mature theories on imagination as the very quality not of Christians but of Greeks. He writes that "here [imagination] cannot provide any image in which seeing and feeling would be unified". For that reason he concludes by a desperate description of the modern Christian to whom "something divine was promised and it melted away in the mouth" 22 - the reference is of course to the holy communion.

All of his later thought could be seen as the research of strategies to conserve what necessarily must be overcome and sublated. If he knew well, as we saw, that regret follows the loss of images, we must suppose that his final doctrine is based in a more comprehensive image theory than a mere iconoclasm that apparently could be expressed by phrases, as the one on the holy communion we just saw, taken from his Lutheran heritage.

\section{From Human Image to Speculative Likeness}

If now we turn to the Lectures on History of Philosophy, the section that corresponds to our period is the one dedicated to Neoplatonists. The

[20] GW: G.W.F. Hegel, Gesammelte Werke, Bd. 2: Frühe Schriften II, Text 55, ed. by W. Jaeschke, Meiner, Frankfurt a.M.: 2014, 242-43; engl. trans.: On Christianity, Early Theological Writings; trans. by T.M. Knox, Harper \& Brothers, New York: 1961, p. 252.

[21] Symposium, 21, 22.

[22] GW2, 244; On Christianity..., cit., p. 253. 
fact that the whole section is dominated by the issue of images is given at the conclusion of this section. There, Hegel focuses on our issue:

\begin{abstract}
So the statues and paintings of artists exhibit the inner speculative thinking, the state of being imbued with the divine, that brings itself to outward expression. The consecration of images is also represented in this way; within it we see the connection expressed more precisely, because the Neoplatonists regarded both the mystical element and the external images (die äußeren Bilder) as animated by the divine itself. These are phenomena (Sie sind Erscheinungen) that God communicates in keeping with his endless goodness, so that the divine energy is present in [all these] images (Bildern). I wanted to call to mind this aspect of Neoplatonism only because it played a major role in that period ${ }^{23}$.
\end{abstract}

It is really surprising that Hegel remarks this peculiarity of the late antiquity. But the fact that here the production of images follows the speculative thought and not the opposite is much more peculiar. This means that the production of images is justified by Hegel not only as a propaedeutic to rational thought, but also as a return to the material world in order to redeem it.

This is the great change from Greek antiquity's image conception to a theurgic conception in the late antiquity. In classical Greece, nobody felt that it was their duty to redeem anything. The concept of redemption was unknown ${ }^{24}$. But why are the Greeks now searching for spiritual redemption? Hegel explains this passage through the Roman mediation. It is because of the corruption, the spiritual poverty, the individualism, the abstract forms of State and Law and so on that the Greeks lost their faith in the beautiful union between real and ideal, form and matter, interiority and State. Again, Hegel chooses this moment to speak about the split and convergence between Religion and Philosophy. Acutely he finds the crossroad of all tendencies in Alexandria, were Greeks, Jews and Christians were living and studying side by side.

For Hegel there is a common root between the Christian religion and Greek philosophy. That root is to be found in the Alexandrian school of Neoplatonists and in Church Fathers. It seems that for Hegel, the real split was made not between Christianity and the Greek world but between religion and the State. The real enemy of the Spirit in the first centuries

[23] V8, pp. 190-91; Lectures on the History of Philosophy 1825-6, Volume II: Greek Philosophy, trans. and ed. by R. F. Brown, Oxford University Press, Oxford: 2006, p. 345.

[24] The only use of the word apolytrosis in ancient texts has the meaning to let one go freewhen captured as a hostage - upon receiving the price requested, as in Plato (Legg. 11, 919a.) and in Plutarch (The Life of Pompey, 24). It is only by Paul that we have the concept of $\tau \dot{\eta} v$

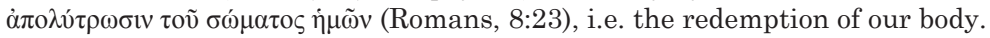


was the abstract universality and the external finalism of the Roman Empire, implanted in religion. Even the Latin religio, for Hegel means only "a relation of constraint and dependence" 25 . But philosophy, through stoicism and skepticism, prepared the soil for Christianity, highlighting the solitude of mankind in Roman world. We could say that Hegel sees in these first centuries collaboration between Greek, Jewish and Christian thought with the only aim of offering a higher and more speculative Truth to the Human consciousness. This Truth that rose in Alexandria was the Idea of Trinity.

As we said, Hegel recognizes a great importance in images in this period. He creates a very thin opposition internal to the Greek culture. He opposes the old philosophers, such as Plato, to the last Pagans by saying that the first was totally against mythology, and for that reason he has been accused of atheism. On the contrary, Alexandrines "endeavored to demonstrate a speculative truth in the Greek images of gods (Götterbildern)". ${ }^{26}$

In this reflection, Hegel caught the very change of paradigm in the passage from the Pagan to the Christian world. What seems extraordinary is the fact that Hegel quotes, right after, the Emperor Julian as the one "asserting that the pagan ceremonials had a strict connection with rationality". What does this phrase mean for the use of images? That "the [Pagans] felt, as it were, obliged to give to their divinities the semblance of something higher than sensuous conceptions; they therefore attempted to spiritualize them"27. To get an idea of the importance of this short observation, we could quote Julian's letter to a priest. ${ }^{28}$ The Emperor defended the practice of image-worship as something given by tradition "as symbols of the presence of the gods" ${ }^{29}$. Images and statues, says Julian, have been given "not that we may regard such things as gods, but that we may worship the gods through them". But Julian adds something more than the mere rationality that we found before as an argument in Porphyry. He says, "since we are in a body, in bodily wise we must perform our service to the gods". But why does Julian give all these advices to a priest? If we read the text carefully, we can understand that the Emperor gives an image theory

[25] W12, p. 352; LPhH, p. 308: "The Roman spirit which thus remained involved in subjectivity, came into a relation of constraint and dependence, to which the origin of the word "re-ligio" (lig-are) points".

[26] W12, p. 399; modified trans. in: LPhH, p. 347.

[27] W12, p. 400; LPhH, pp. 347-48.

[28] See: Julian the Emperor, Fragment of a letter to a priest, in: Id., Works, trans. by W.C. Wright, Loeb Classical Library, 1913, vol.2, pp.297-339.

[29] Ibid., 293b. 
in response to an Iconoclastic act done by the Christians. ${ }^{30}$ As Christians will do more than three centuries later, Greeks created a theory of images in response to the Christian iconoclastic wave that was growing in the Empire. Clement of Alexandria and Origen, or later, in the times of Julian, Eusebius of Caesarea, and Epiphanius of Salamis will attack images in the name of their Christian Neoplatonism, while Porphyry, Iamblichus, and Julian will create a pagan image theory very similar in some aspects to what we find today in the Eastern Theology of Icons.

Hegel understands this complex historical situation well, and instead of choosing an external, political explanation to the decay of the Roman Empire, he tries to understand the conceptual necessity behind history. In that sense, he points out that what took place in Alexandria and consequently revolutionized the world is the conception of Trinity as a concrete God, as Spirit. That was not a Christian discovery at all. First it as the contribution of a Jew, Philo of Alexandria, and then, as universal method, it was established by Proclus.

According to Hegel, the key concept that makes a special connection between an image theory and the Idea of Trinity, for all the late antiquity, is the concept of logos:

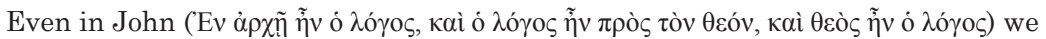
see the commencement of a profounder comprehension. The profoundest thought is connected with the figure of Christ - with the historical and external one. ${ }^{31}$

This is a clear case in which we could not grasp the richness of his thought, without a theory of image to help us. John's verse (1:1) is not the verse that speaks about God who became flesh (1:14), which also will be used by the later Church Fathers to defend Icons. This verse speaks only about logos. Over and above all difficulties, we could admit that logos is

[30] Further, Julian writes: "Therefore let no man disbelieve in gods because he sees and hears that certain persons have profaned their images and temples". In another case, we know that it was fire at a temple of Apollo, caused by Christians, to unleash the wrath of the Emperor. For the struggles between Christians and Pagans at the time of Julian, see P. АтнNASIADI, Julian. An Intellectual biography (Routledge, London: 1992); B. Lincoln, "Violence", in: The Cambridge Companion to Ancient Mediterranean Religions, ed. by B. S. Spaeth, Cambridge University Press, Cambridge: 2013; D. R. Edwards, Religion and Power: Pagans, Jews, and Christians in the Greek East, Oxford University Press, 1996; on the theoretical aspects of their conflicts, see: Apologetics in the Roman Empire: Pagans, Jews, and Christians, ed. by M.J. Edwards, M. Goodman, S. Price, Ch. Rowland, Oxford University Press 1999; L'intolleranza cristiana nei confronti dei pagani, ed. by P.F. Beatrice, EDB, Bologna: 1993.

[31] W12, p. 401; LPhH, p. 348. 
the key to establish the convergence between Greek philosophy and monotheistic religions. ${ }^{32}$

If in the first passage that I quoted, at the beginning of this paper, we had the principle of an Image theory based on the necessity of appearance, here, the last principle with which we establish the necessity of disappearance, is coming forth.

Before coming to this, however, I would like to note that Hegel never translates the Greek word "logos" in his works. If he had to translate it, he would have had to have done it by the common Lutheran translation of "logos" as "word". But he knows well that logos is not only "word"; it is much more ${ }^{33}$. Actually, logos could be at the same time both word and image. To understand this oddity, we have to go again to the sources of Alexandria, and particularly to Philo. He is the one that conceived God as Spirit, that is to say, in His concrete determination as logos. ${ }^{34}$

What Hegel initially remarks in the philosophy of Philo is his theory of öpaбis, of vision; and he explains that for Philo the first act of the soul in its elevation to God is contemplation as vision, something similar to intellectual intuition. But the problem is that through vision the soul comes to know that God is, but not what God is. The sense of this claim in a theory of knowledge and consequently in theology is explained by Hegel in a passage that sounds like a master-class on images as only Byzantine Philosophers have pronounced in the past. by noting:

He starts the exposition of the second main point of Philo's theory

[32] But Hegel is also aware of the danger of heresy. All heresies are founded here, he notes. How could we avoid them? By not hypostatizing Logos apart from the universal since it "has already itself the characteristic of return within itself, [since it] contains a moment that (must be distinguished) in order to comprehend the distinction exactly. The resolution consists in the fact that Spirit is the totality, and the first moment itself is grasped as first only because, to begin with, it has the determination of the third, of activity"; see: V5, pp. 23-24; LPhR, III: The consummate religion, ed. by P. Hodson, University of California Press, 1985 , p. 86.

[33] See, for instance, how Neander tries to give more and more explications on what logos really means, not only in the Gnostics' doctrine but in Philo's too (in: A. NEander, Genetische Entwicklung der vornehmsten gnostischen Systeme, Berlin 1818, pp. 13 ff.); after all the explanations, he still keeps on always using the Greek word, something that Hegel should surely have noticed reading this book.

[34] See: W12, p. 399; LPhH, p. 347, where Hegel speaks about that and again he uses the word logos in Greek: "It is especially remarkable to observe there, learned Jews such as Philo, connecting abstract forms of the concrete, which they derived from Plato and Aristotle, with their conception of the Infinite, and recognizing God according to the more concrete idea of Spirit, under the definition of the logos". 
Secondly: "God's image and reflection is $\Lambda$ óyos, thinking reason, the First-born Son, who rules and regulates the world". Here, verily we come upon a contradiction; for the image can only represent what the thing is; if therefore the image is concrete, its original must also be understood to be concrete. "This $\Lambda$ óyos is the innermost meaning of all Ideas"; God Himself, in contrast to this, as the One, as such, is only the ovv, the pure Being - (as in Plato) ${ }^{35}$.

The contradiction that Philo emphasizes is the contradiction that animates the idea of Trinity. Namely, the Idea that God as One is only an abstract God and by the means of logos he mediates himself with the world..$^{36}$ For the first time we are facing the birth of the notion of Trinity as something essential to the concept of God. This is a main point that could explain what Hegel means when he says that Christian dogmas have been elaborated on by philosophers and that it is right to keep them alive. But, returning to Philo, we can see that he presents another aspect that Hegel appreciates a lot: the distinction and the simultaneous unity of the double meaning of logos. First as image, and then as dóyos профорıко́s, namely, oral speech. If it is by the power of word that God creates the Universe, it is by the power of image that He creates mankind. When Philo makes comments upon the famous biblical passage of human creation ${ }^{37}$ he insists that eikona means the rational likeness to God. Once again and through another way, we have the equivalence of Logos and Image. So, it is because

[35] LHPh: Lectures on the History of Philosophy, 3 voll., trans. by E.S. Haldane, London 1892, vol. II, p. 391; italics are mine and translation modified in order to follow better the W19: Vorlesungen über die Geschichte der Philosophie II, p. 421: "Zweitens: "Das Ebenbild und der Abglanz Gottes ist der $\Lambda$ óyos, die denkende Vernunft, der erstgeborene Sohn, der die Welt regiert und in Ordnung hält." Eigentlich ist dies schon ein Widerspruch; denn das Bild kann nur darstellen, was die Sache ist; ist also das Bild konkret, so ist auch das Ursprüngliche als konkret zu fassen. "Dieser $\Lambda$ ó ${ }^{\circ} \varsigma$ ist der Inbegriff aller Ideen." Gott selber dagegen als der Eine, als solcher, ist nur das óv, das reine Sein (nach Platon)"; On Philo's idea of the erstgeborene Sohn, we can find in De somniis, 215, as follows: "For there are, as it seems, two temples belonging to God; one being this world, in which the high priest is the divine word, his own firstborn son [o protogonos autou theios logos]. The other is the rational soul, the priest of which is the real true man, the copy of whom, perceptible to the senses, is he who performs his paternal vows and sacrifices, to whom it is enjoined to put on the aforesaid tunic, the representation of the universal heaven, in order that the world may join with the man in offering sacrifice, and that the man may likewise co-operate with the universe".

[36] Not even the appearance of Plato's name in this context is accidental. A lot of philosophers spoke of God as abstract being. The difference is that Plato also spoke of the world as eikon, image, and -the most important- as the only-begotten Son of God. See, Timaeus, 92c:

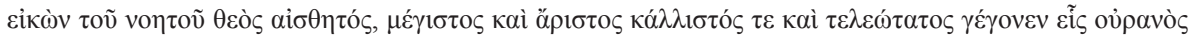

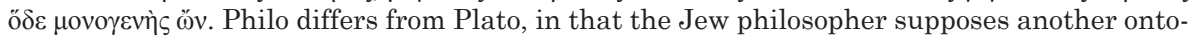
logical structure than the Greek: for Philo the world is image of Logos, that in turn, is image of God.

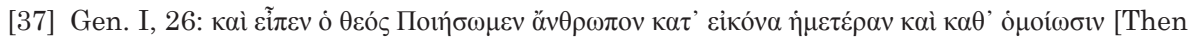
God said, "Let us make man in our image, after our likeness"]. 
of Image that the contradiction enters in the life of God, or if we prefer, in the original Idea, in the sense that the Ur-bild becomes Eben-bild, the One becomes Other than itself.

There is no text belonging to this period, neither from the Pagans, nor from the Christians, that by fighting against idolatry does not develop a philosophy of image as well. We saw the importance given to Philo and to his conception of image as logos. On the contrary, other philosophers, Hegel claims, "cannot be altogether absolved from the charge of superstition" for "they asserted in reference to the worship of images that these really were filled with the divine power and presence" 38 .

That second way of considering image in late antiquity is what is known as theurgy. The only one that is explicitly excluded from this accusation is Plotinus:

Except the quite theoretical observation regarding the images of the gods which we mentioned above, the writings of Plotinus contain nothing in any way related thereto.$^{39}$

The problem is that if one takes a look at the text, there is no mention "above" to Plotinus' philosophy of image. However, we cannot give up our effort now, as it is clear that after Philo, this is the only moment in which Hegel gives his explicit approval of an image theory.

In the preceding page, without any literal quotation, Hegel begins to speak about the role of magic in Plotinus. This "inadequate conception of natural relations", is justified by Plotinus through the "law of sympathy" ${ }^{40}$. If Hegel really read this original text in order to criticize magic, he certainly found also an outline of Plotinus' philosophy of image ${ }^{41}$. When

[38] W19, p. 441; LHPh., II, p. 409-10.

[39] W19, p. 442; LHPh., II, p. 410.

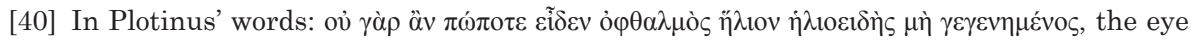
could not contemplate the Sun if it was not similar to the Sun. This, however, is not any

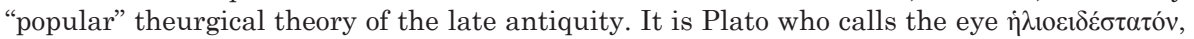
i.e. sunlike.

[41] The other text where Plotinus speaks extensively about magic is the 4th book of the 4th Ennead. The content, however, is quite different from what Hegel attributes to Plotinus. There, on the contrary, the Greek philosopher achieves a high level of rationalization of what popular magic-beliefs are. There, Plotinus exposes the magic theories, but what is certain is

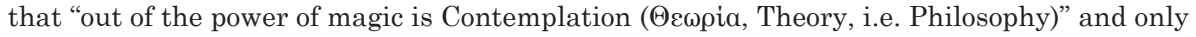
"he who contemplates ( $\theta \varepsilon \omega \rho o u j \mu \varepsilon v o v) ~ h i m s e l f$, is secure against any spell" (IV, 4, 44). It seems that Plotinus considers the popular beliefs only to take distances showing that Reason is untouchable by any spell. 
Hegel speaks about Plotinus's theory of images, he must have in mind a text where the rest of the references to magic must be included; that text could not be other than the 6th Book of the 1st Ennead.

We are at the very crossing of the entire late antiquity: Plotinus tries to explain how somebody could contemplate the supreme Beauty ${ }^{42}$. But how does he choose to express it? He chooses to do so by the description of a worship-ritual in a temple; and this is quite a strange ritual. He says that the philosopher shall do what a priest does: he must throw away his usual clothes, and while ascending to God he has to dismiss whatever is foreign to divine ${ }^{43}$. His aesthetics of vision demands "not to see", ${ }^{44}$ but to leave everything behind, even the act of seeing itself. But somebody else has already described this procession: we are back again to Philo the Jew. He writes:

The high priest will not come into the Sancta Sanctorum clad in a garment reaching to the feet; but having put off the robe of opinion and vain fancy of the soul

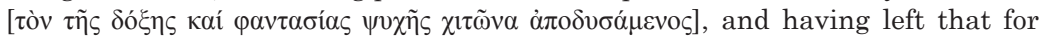
those who love external things, and who honor opinion in preference to truth, will come forward naked, without colors or any sounds, to make an offering of the blood of the soul, and to sacrifice the whole mind to God. ${ }^{45}$

The Jew and the Pagan are almost in literal convergence. He who searches the Beauty in material bodies, says Plotinus, has to know that it is only a shadow, a trace, only an image. On the contrary, our aim is to reach, through images, to what has no image. The punishment for he who loves images is worse than the punishment of Narcissus, as he would fall not into the water with his body but into the darkness of Intelligence with his soul. ${ }^{46}$ This tremendous Iconoclasm, is not what the word "iconoclasm" literally means. For a philosopher does not break any image; he breaks fancies and opinions.

Now, the third step in the Greek world of the late antiquity is to be found in the Fathers of the Church. Here, we have to recognize the most important convergence, for Hegel, of Philosophy and Religion. With the Church Fathers we have the perfect fusion of Revelation and Reason; Hegel says that this is their task in a double sense: on the one hand, Neoplatonic philosophy has to become an object of common consciousness,

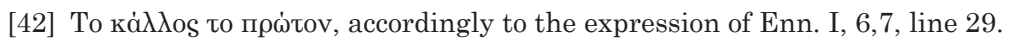

[43] See: Enn. I, 6,7.

[44] Enn. I, 7,8.

[45] Allegorical Interpretation, II, 56.

[46] Enn. I, 6,8. 
accessible to all. By the success of this task, later, Hegel will also explain the universal spread of Christianity. On the other hand, Religion has to be elevated to the level of Philosophy. This means that all of the historical facts that the apostles have lived and seen should be elaborated in a universal form, able to be learned and understood by everyone, without being attached upon sensible facts of the past that no one recognizes anymore.

The sensuous [figure] must disappear (die sinnliche Gestalt verschwinden muß), so that it may be received by Recollection (Erinnerung), taken into the Mnemosyne, into the realm of Representation (Vorstellung) and must be removed away from the sensuous Present (aus der sinnlichen Gegenwart). Then for the first time can the spiritual consciousness, the spiritual relation (geistige Bewußtsein, Verhältnis), come forth. ${ }^{47}$

At the end of this passage, Hegel writes that "the truth of the Idea of spirit must be known as concrete spirit, and this is the form peculiar to the Fathers of the Church". As we saw before, Hegel deduces a justification of images through the concreteness of God. Now, he speaks about the necessary disappearance of the sensuous figure. This is the highest contradiction that will be proper to the whole Christian world and particularly to Christian art. The western aesthetics of religion will be cultivated upon this contradictory ground: on the one hand, the necessity to express in a concrete way the Spirit, and on the other hand, the consciousness of this impossibility.

Only in order to give an idea of the complexity of Hegel's words, we could add a few notes to the text just quoted. For instance, in spite of Hegel's reference to the Church Fathers, we have to note that, actually, the

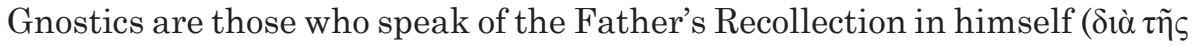
'Ev $\theta 0 \mu \eta \dot{\sigma} \sigma \varepsilon \omega \varsigma \tau \tilde{\eta} \varsigma \dot{\varepsilon} \alpha v \tau \sigma \tilde{)})$ and the production of the Son as Image that must

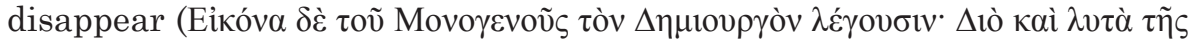

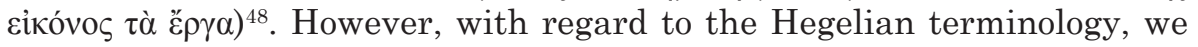

[47] W19, p. 505; LHPh. III, p. 15.

[48] Excerpta ex Theodoto [I] 7,5; for a Gnostic interpretation of John's verse, see: Exc.Th., [I] 6; on recollection: Exc.Th. [I] 7,1. As we said at the beginning, Hegel's relation to the Gnostic sources would be a matter of investigation in itself. We could only note that, in the main text, which we know surely that Hegel read, the Genetische Entwicklung..., cit., by Neander, there is a chapter dedicated to Theodotus (see: ibid, pp.187-190). However, what is important here is that there is not any reference to the doctrine of recollection (a doctrine which appears in that book only once -p.239 as kosmike lethe - but even so we know well that was important for the Gnostics). Nevertheless, there is a reference to the doctrine of the image of logos (Bild des logos), that Neander connects again with Philo and one of his figurative expressions (very similar to the one we already saw), called iereus tou ontos, literally "priest of the Being", which would be an equivalent of Bild des logos (see: ibid, p.188). The 
can also make a distinction, by translating the terms of Hegel's lecture in his later System of Knowledge. So we should distinguish, according to the doctrine of Subjective Spirit, between a "recollection" (Erinnerung) that "inwardizes" images ${ }^{49}$, and a memory (Gedächtnis) that unloads images in order to produce concepts. In the Lectures on Philosophy of Spirit (1827), Mnemosyne is used as a synonym not of recollection but of memory ${ }^{50}$; hence, what we just read makes sense. It is not only by "recollection" that images must disappear but "in the realm of representation", i.e. in their transition from "recollection" to "memory", mediated by imagination ${ }^{51}$.

\section{Conclusion: An endogenous iconoclasm of the image}

In conclusion, I would like to observe that what Hegel points out clearly in this complex period is that the historical transition from one aesthetic conception to another, is connected to the need of concreteness for the conception of divine and that this concreteness is represented by the speculative life of the Trinity. First, conceived as philosophical Idea in Neoplatonists and then, conceived as theological one in Christianity. But if the significance of Trinity is a complete movement of return to the One, it means that 'alienation' is not only a process of emanation, but also that the return back to the fulfillment of the Substance from the alienation should be realized concretely, by recognizing ourselves in - and not against - the Otherness and its externality. If this alienation has been seen as "Creation of the world", or as "Incarnation of Logos", and if this incarnation has been recognized as the very foundation of any figural representation of God, how could the third moment of Trinity, the spiritual reversion to the One be seen or represented? Of course, it has to be aniconic and that is the

Italian scholar ALdo MAGRIs paid attention to the Gnostic Image Theory in his La Logica del Pensiero Gnostico, Morcelliana, Brescia 1997, pp. 151-204; I owe to him the discovery of the important verse of Theodotus (ibid. p.154).

[49] : Vorlesung über die Philosophie des Geistes. Berlin 1827/1828. Ed. by F. Hespe and B. Tuschling, Meiner, Hamburg 1994, p. 200; LPhS: Lectures on the Philosophy of Spirit 182728, trans. by R. Williams, Oxford University Press, Oxford 2007, p. 217: "Recollection proper includes the inwardizing of the image in the intelligence, not the disappearance from, but the complete immersion of the image in the intelligence".

[50] V13, p. 208; LPhS, p. 224.

[51] If that is right, then we could find a real connection with another patristic doctrine,

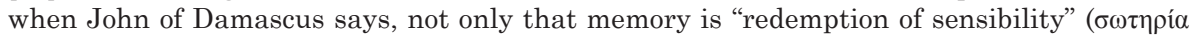

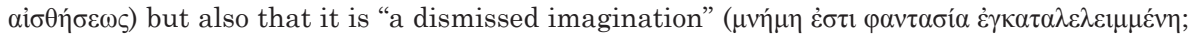
De Fide Orthodoxa, II, §20); but as far as I know, there is no mention of this Greek author in Hegel's works or lectures, so for the moment we couldn't assert a real or direct connection between them. Nevertheless, the similarity between them is remarkable because the expression of Damascene seems unique in the philosophical literature before Hegel. 
iconoclastic element of this theory. However, it is not a simple iconoclasm. If the first aniconic moment was an immediate placement of spiritual into something material - as a mere "formlose, heilige Stein", a formless holy stone that Hegel despises so much ${ }^{52}$ - this aniconic final stage is something that has been mediated by the image.

This is the absolute originality of the Hegelian philosophy, that could be an absolute novelty for a theory of image today: the iconoclastic tendency is not something external, but something endogenous, internal to the image. This has really revolutionary consequences for all of our topics: a) historically, we have to reconsider what iconophilia and consequently iconoclasm mean; b) theoretically, we have to understand the internal tensions of the image, and not what politics or marketing want to do with them; c) once the internal dialectics of images are known, we have to evaluate all of our mental attitudes towards image-issues differently.

Thus, I am convinced that, by inverting this view on images, a completely inverted world would come forth. Only then, the images of Religion could be understood conceptually and the concepts of Philosophy could find their successful embodiment. Let me close this paper with a last quotation from Hegel that, once again, expresses in a concise way the complex relation between Philosophy, Religion and Images:

\begin{abstract}
Whatever stage it may itself have reached, the Truth must undoubtedly in the first place come to men from without (in äußerlicher Weise) as a present object (gegenwärtiger Gegenstand), sensuously represented (als sinnlich vorgestellter), just as Moses saw God in the fiery bush, and as the Greek brought the god into conscious being by means of sculpture (Marmorbildern) or other representations (Vorstellungen). But there is the further fact, that neither in Religion nor in Philosophy does this external form remain, nor can it so remain. A form of the imagination or an historical form (Solche Gestalt der Phantasie oder geschichtlicher Inhalt), such as Christ, must for the spirit be spiritual; and thus it ceases to be an external matter, seeing that the form of externality is dead (die äußerliche Weise ist die geistlose). We must know God "in Spirit and in Truth". He is the absolute and actual Spirit (Gott ist der allgemeine, der absolute, wesentliche Geist) ${ }^{53}$.
\end{abstract}

[52] W18: Vorlesungen über die Geschichte der Philosophie I, pp. 89-90, p. 95; LHPh, I, p. 69 , p. 74 .

[53] W18, pp. 92-93; I left the trans. as in: LHPh. I, pp. 71-72, but the slight differences from the original are clear. On the same issue, see also: V6: Vorlesungen über die Geschichte der Philosophie, Teil 1: Einleitung in die Geschichte der Philosophie. Orientalische Philosophie, ed. by P. Garniron and W. Jaeschke, Hamburg 1994, pp. 66. 
